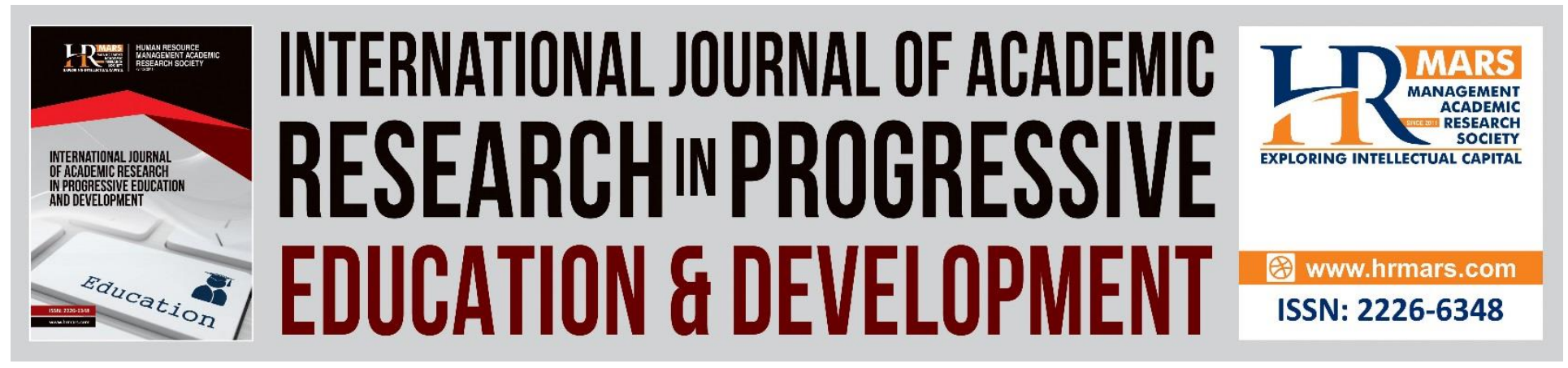

\title{
Case Study Approach: Outlook on Learning Strategy and Style among Malaysian Rural Pupils.
}

Faridah Mahadi, Mohd Razimi Husin

To Link this Article: http://dx.doi.org/10.6007/IJARPED/v10-i2/9722

DOI:10.6007/IJARPED/v10-i2/9722

Received: 04 February 2021, Revised: 28 February 2021, Accepted: 19 March 2021

Published Online: 17 April 2021

In-Text Citation: (Mahadi \& Husin, 2021)

To Cite this Article: Mahadi, F., \& Husin, M. R. (2021). Case Study Approach: Outlook on Learning Strategy and Style among Malaysian Rural Pupils. International Journal of Academic Research in Progressive Education and Development, 10(2), 35-48.

Copyright: (C) 2021 The Author(s)

Published by Human Resource Management Academic Research Society (www.hrmars.com)

This article is published under the Creative Commons Attribution (CC BY 4.0) license. Anyone may reproduce, distribute, translate and create derivative works of this article (for both commercial and non-commercial purposes), subject to full attribution to the original publication and authors. The full terms of this license may be seen

at: http://creativecommons.org/licences/by/4.0/legalcode

Vol. 10(2) 2021, Pg. 35 - 48

http://hrmars.com/index.php/pages/detail/IJARPED

JOURNAL HOMEPAGE

Full Terms \& Conditions of access and use can be found at http://hrmars.com/index.php/pages/detail/publication-ethics 


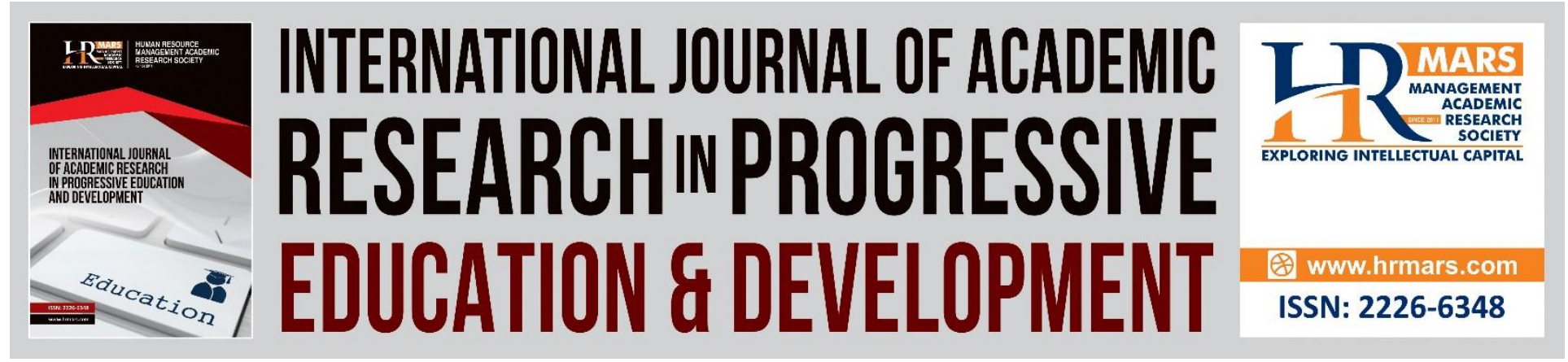

\title{
Case Study Approach: Outlook on Learning Strategy and Style among Malaysian Rural Pupils.
}

\author{
Faridah Mahadi, Mohd Razimi Husin \\ Universiti Pendidikan Sultan Idris, Tanjong Malim, Perak, Malaysia
}

\begin{abstract}
This article presents the case study as a part of research exploration. Its aim is to give a detailed image of a case study - its definition, some classifications, and several advantages and misunderstanding - in order to provide a better understanding of this widely used type of qualitative approach. This article goes through the process of considering pupils from rural area in Malaysia to be as participant. The research investigates how and why the learning strategy and style give impact to their learning process. It might answer the question of 'how' and 'why' in the research questions. Single-case study had been choosing as the design of the case because it involves single part in context and case.
\end{abstract}

Keywords: Case Study, Types of Case Study, Qualitative Research, Single-Case Study

\section{Introduction}

Case study was a major methodological player in research world and it is one of the first types of research used in qualitative mode. Nowadays, they account for a large scale of the research presented in books and articles in psychology, history, medicine and education. Cope (2015) claims that case study research is regularly prescribe as an adjustable but challenging approach that is most frequently used in social science. Case studies have been being found to be valuable in practice-oriented fields such as education, management and social work. But in contempt of its long history and overall use, case study research has received little attention among the various methodologies in social science research.

According to the writers of the Encyclopaedia of Case Study Research (Mills, 2010), only a few content deal directly with case studies as an essential subject. Thomas (2011) stated, "Most research approach texts either neglect case studies or confuse it with other types of social studies." From this, we can wrap up that indeed of their boundless use and popularity, case studies are classify by uncertainty and inconsistencies in understanding their definition, subjects of investigation, and methodological choice (Verschuren, 2003).

Case study is the frequently used in qualitative research approach. After all, it does have a consistence condition as a social science research procedure because it does not have actual and well-structured code (Yin, 2002), so new researchers who decide to apply case study 
normally get distracted "as to what a case study is and how it can be different from the other sort of qualitative research approach" (Merriam, 1998).

Based on the above definition of case study, researcher chooses to use this research method in order to answer the research objective of the research. In order to gather a 'rich' finding about the strategies and style of learning preferred by Malaysians' rural pupils, researcher considered case study as the best tool. It is suit with this method because this study complies with the qualitative studies that have been detailed by Merriam (1998), which focus on understanding in depth how a student's style and strategies are engaged in their learning routine.

Learning is an effective social development involves learners to generate new facts and concept based on their background knowledge. According to Rigel and Haryanto (2016), in the learning development, learner faced many goals that need to be achieved. In order to obtain the goal, there are many approach can be implemented. Those are such as by adapting learning strategy and learning style.

This study does not predict or involve a generalization statement; rather it seeks to understand the learning styles and strategies adopted by students during the learning process. It aims to address the types of strategies and strategies that students practice.

This research process is guided by the research questions; (1) What is the dominant language learning strategy and style for Malaysian rural pupils? (2) Why those dominant learning strategy and style affect their learning routine? (3) How is the motivational role of language learning strategies and learning styles give impact to Malaysian rural pupils?

Learning strategies are the ways in which pupils learn, memorize information and study for tests. They refer to the actions pupils use to learn. In another way, learning styles refer to the general approaches that pupils use in getting and adapting a new information or subject.

\section{What is Case? What is case Study?}

What is a case study and why is it different from the other styles of research approach? Obviously, researchers have many ideas in their attention when discuss on case study research. Gustafsson (2017) notes that cases study should be simple to understand to achieve its aim. The researcher should identify the audience of the study and try to compare it to published facts to make it reliable.

Phenomenon is the word that difficult to avoid when discussing about case. It helps us to remark the circumstance should be observed. Yin (2018), agrees that by defining case as a latest phenomenon with in it actual routine context, exclusively when the borders between a phenomenon and context are not clear. Researchers have limited control over the phenomenon and context. The case in this context of research is a group of pupils from rural area in Malaysia. The researcher would like to observe this group in their 'natural' setting where they belong to. Beside the main case, the study also need to consider another voice or different angle of idea from person which relevant with the case. In this study, the researcher found out that teachers and parent's perspective should consider in analysing the data. Teacher is the person who has close contact with the pupils in school and at home we have their parents.

Otherwise, case is defines as a clear cut, a complex and functioning items by Stake (1995). He added that case also simply defines as "an integrated system" which has limit with its own working components. According to Merriam (1998), case might be a people, a plan, a group, a 
specific policy and so on. Compared to Yin and Stake, Merriam has come out with more comprehensive list in defined the word case itself. Meanwhile according to Easton (2010), case is a single item and the sample should be enough of one. A case also can be of various sizes lean on the object of the case study. It might be a nation, a business, a group, a family or an individual (Gerring, 2007). Selecting cases must be done so as to maximize what can be learned in the period of time available for the study.

In general, case study refer to task that involved (a) small number of $N$ ( Yin, 1994); (b) research that involved ethnographic, participant-observation, clinical and 'in the field' (Yin, 1994); (c) research classified by process-tracing (George \& Bennett, 2005); or (d) the research explore the plot of single case and phenomenon (Eckstein, 1992).

There are numerous definitions of case studies, ranging from general to specific. The attempt of many writers to clear up the concept of a case study and they have repeatedly lead to a definitional mishmash because no matter when someone tries to simplify the confusion using definitions, it only makes it more complicated (Gerring, 2004). Flyvbjerg (2011) notes that if a definition of a case study is needed, it is better that it is more general and does not contain plenty of accurate descriptions. Yet, we cannot claim that the definition of a case study is needless because it is the definition that places the case study within its own field and gives it its own characteristics in contrast to other version of qualitative research. According to Flyvbjerg (2006) case study is a context-dependent, comprehensive review of a single example of a phenomenon. This statement was acknowledged by Elman (2016), by claims that a case study "focuses intensively on a single case" and case is expected to represent a larger group of cases.

Straight-forward observation has been described as the vital standard among qualitative data collection. In this study, observation is the key tools to gather the data. Observation focuses the pupils in their daily routine in learning. Besides that, the observations also carry out beyond the classroom activity. According to Alarcón et al (2019) the most frequent learning strategies and style on the part of the students were investigate from the observations made. Yin (2009) also defined case study as an observational inquiry that consider the case by answering the 'how' and 'why' concerning the phenomenon of interest which is beyond the researcher's control. Yin notes that case studies are research condition where the variable of interest for outstrips the number of data points. Hyett, Nerida and Kenny (2014) agrees with Yin and claims that researchers practice the case study in order to identify what is familiar about the case and what is precise about it to explain 'how' and 'why' specifically.

As mentioned above, case study analysed the "why and how" questions for the issue under investigation (Marcella, 2018). The "why" questions in the study was focussed on reason of Malaysian rural pupils used learning strategy and style in their learning routine. The "how" questions generally addressed the choices of the pupils in choosing their preferred learning strategy and style.

The combination of few technique and approach build the belief in scaffolding the case study. Stake (1995) noted case study as the study of an "integrated system". Stake also come out with four characteristics in defining qualitative case study; holistic, empirical, interpretive and empathic. In holistic research Stake agreed with Yin which is they said that the researcher should consider the interrelationship between the phenomenon and its context. Second characteristic is empirical; in this field of study the researcher base their study on their observation in the field. 
For interpretive, the researcher used their intuition and go through the research essentially as a research-subject interaction. In emphatic, researcher reflects the indirect experiences of respondent in a significant perspective. Merriam (1998) clearly defined it as an intensive, comprehensive description and analysis of a belted phenomenon like an activity, an institution, a group or a person. According to Merriam, case study is unique based on its distinctive attribute such as (a) particularistic which means focus on particular phenomenon, situation, activity or event; (b)descriptive in order to crops a rich and thick description of the phenomenon of study and (c) heuristic helps illuminates the viewer's understanding of phenomenon under the study.

Case study is an instance of a group of program or event which is refer to the term 'phenomenon'. The phenomenon consists of scientific interest that the researchers choose to study with the aim of developing theory based on the similarities or differences among the cases of that group of program or event (George \& Bennet, 2005). In simple way, Miles and Huberman (1994) claim case study as a phenomenon that happen in a specific bounded context.

Holistic and in- depth investigation are the main area of case study and this was agreed by Simons (2009) by come out with the definition of a case study based on a critical review that needs commonalities of numerous case study definitions: "Case study is an in-depth exploration from multiple perspectives of the complexity and uniqueness of a particular project, policy, institution, program or system in a "real life'". She also highlighted that a case study should not be seen as an approach in and of itself. Rather, it is a framework that may incorporate a number of approaches. Stake admits; he stated that a case study is not a choice, but a kind of a choice of what is to be studied - by whatever methods we choose to study the case.

\section{Design of Case Study}

The method of case study draws various comments in term of its lack of stability as one of research tool. That why the vital element in case studies are to craft the case study's design (Zaidah, 2007). The researchers have to choose whether to use single-case or multiple-case design. It is highly depending on the issues of research question.

In cases where there are no other cases applicable for replication, the researchers can use the single case design. Nock, Michel and Photos (2007) explain single case design refers to specific phenomenon and studied it using a single subject or a small bunch of research subjects. Siggelkow (2007) disagrees that single case study richly can portray the existence of phenomenon but Yin (2003) notes it is better to use a single case study when the researcher wants to study for example an individual or a group of people. Yin also claims that a single case study with embedded units can be used if researcher wants to get the capability to study the case with data analysis within case analyses, between case analyses and cross-case analyses. When the researcher adopts a single case study with embedded units he gains the ability to scrutinize those subunits that are placed within larger cases.

Single-case study contributes additional and an improved theory. They also clarify that it causes the researcher to have a rooted understanding of the exploring subject. Dyer and Wilkins (1991) address that single case studies are better when the researcher wants to come out with a high-quality theory. According to Gerring (2004) the further case studies with scientific article, 
the more likely it is that it is confident in its representativeness and limited observation time for researcher.

Multiple case study used when researcher need to handle a study using more than one case. Multiple case study also known as collective case studies, cross-case, multi-case or comparative case study. According to Zaidah (2007), multiple case studies can be ratifying with real-life case that shows plentiful sources of evidence through replication rather than sampling rationale. Campbell (1975) in Zaidah (2007) notes that by replicating the case by pattern-paired, a technique link several pieces of information from the same case to some theoretical proposition. Multiple case studies also boost and reinforce the previous result.

The consistent findings across the cases can be used to counter the debate that we are describing some trait of your participants. According to Lazar, Feng and Hochheiser (2017), multiple-case studies able to reduce the interest on external validity. After all, these problems will repeat if we are seeking the theoretical replication. Bear in mind that, members of each group must both represent that group relevantly while differing from other groups in the appropriate aspects.

When a multiple case study is applied it comes with both benefits and complications, which is crucial to take notes by the researcher. However, according to Baxter and Jack (2008), keep in mind that there can be costly and time-consuming procedure to accomplish a multiple case study.

After a few decades of research the well-known, Yin (2009) had come out with four fantastic designs for case study which is he divided the single-case and multiple-case into holistic (single-unit of analysis) and embedded (multiple units of analysis). Tight (2017) addresses holistic case study is pattern by a comprehensively qualitative approach that commit on narrative and descriptive of phenomenon. Whereas embedded case study associate with more than one unit or object of analysis. It normally not bounded to qualitative analysis alone (Scholz \& Tietje, 2002).

The four types of design are based on $2 \times 2$ matrixes (Figure 1). First the matrix shows that every single type of design aspires to analyse contextual practises in alliance to the case with borderline between the two sign that differentiate between the case and the context are not really sharp. The matrix then shows that single and multiple case studies reflect different design position, within these two variations, there also can be one or multiple units of analysis. Four types of design come out from these matrixes; 1) single case cum holistic design, 2) single case cum embedded design, 3) multiple cases cum holistic design and 4) multiple cases cum embedded design. 
INTERNATIONAL JOURNAL OF ACADEMIC RESEARCH IN PROGRESSIVE EDUCATION AND DEVELOPMENT

Vol. 10, No. 2, 2021, E-ISSN: 2226-6348 @ 2021 HRMARS

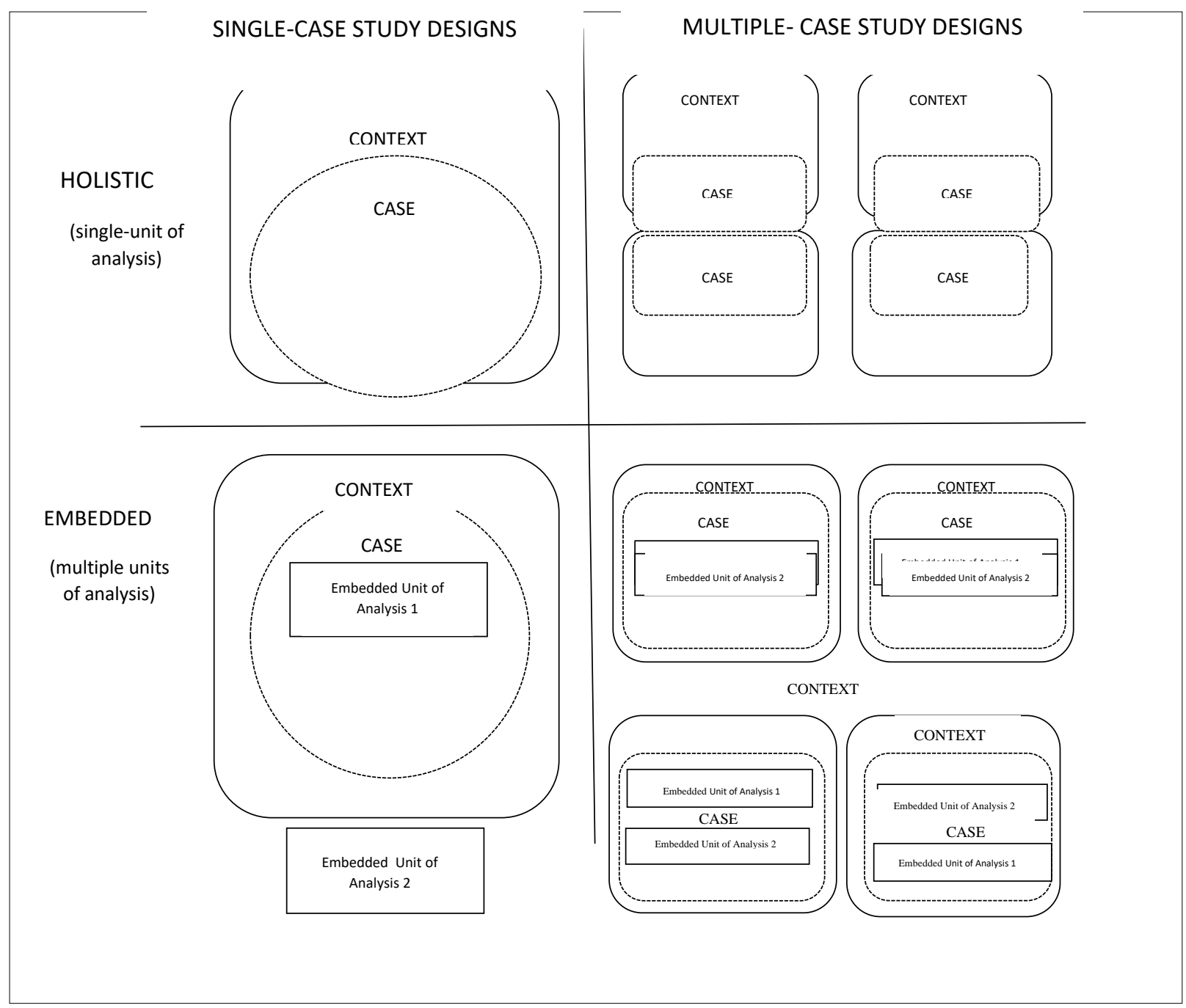

Figure 1. Basic Types of Design for Case Studies (Yin, 2009)

In the related to the study, based on the research questions researcher decide holistic single-case study as a suitable design to conduct the study. The study only involve single analysis unit - a group of pupils with single context- learning strategy and style. It represent clearly in figure 2. 
Vol. 10, No. 2, 2021, E-ISSN: 2226-6348 @ 2021 HRMARS

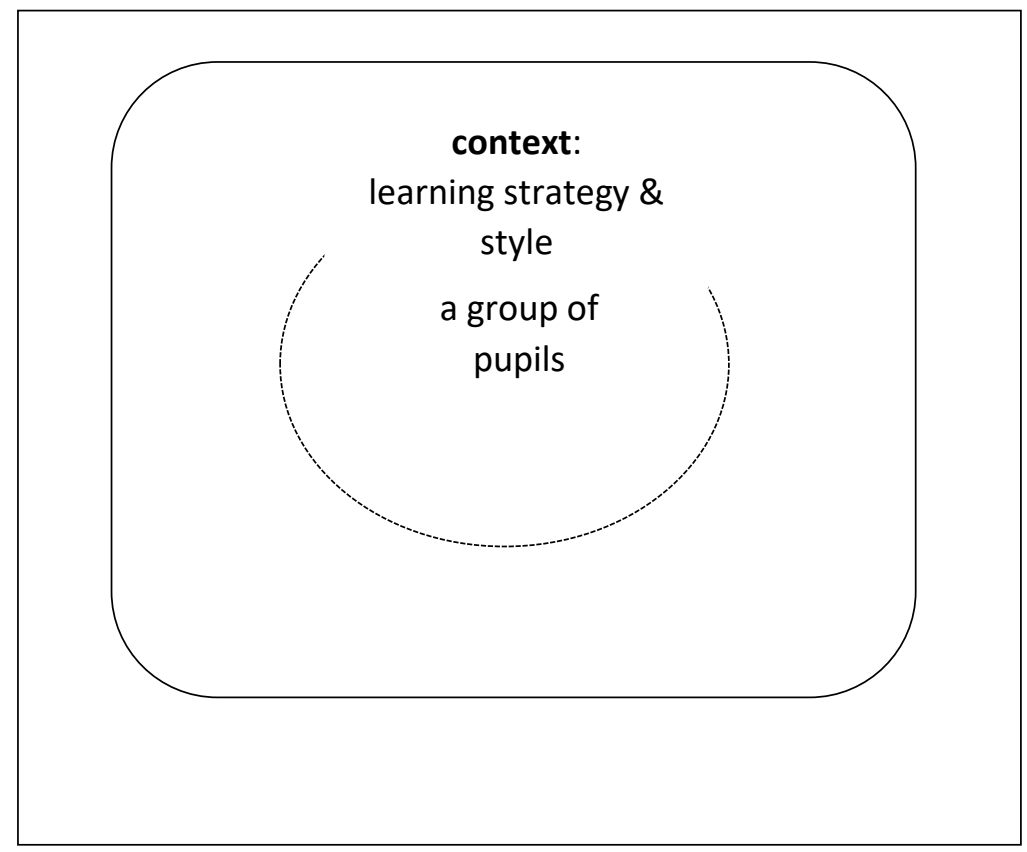

Figure 2. Holistic Single- Case Study adapted from (Yin, 2009)

\section{Types of Case Study}

In long time ago, methodologies have identified that there are various types and approaches in conducting the case study. There are might be similarities among the typologies of case study lists by the researchers or methodologies in conduct the research using case study method.

Case Study definition is usually too general and might not accommodate with its categories or types of case studies. It is almost impractical to cover all types of studies in one single definition. Moreover, researchers offer several of integrative or differentiating categories according to their stated definitions.

Researchers illustrate their own types of case study according to their own understanding and terminology. In table 1 , there are nine alternative typologies of case study and eight of them were recommended in last two decades. 
Table 1. Typologies of Case Study

\begin{tabular}{|c|c|}
\hline Author & Types of Case Study \\
\hline Eckstein, 1975 & $\begin{array}{l}\text { 1. Configurative-idiographic study } \\
\text { - deal with complex collective individuals } \\
\text { 2. Disciplined-configurative study } \\
\text { - apply to cases of framework of inquiry } \\
\text { 3. Heuristic case studies } \\
\text { - 'serving to find out' } \\
\text { 4. Plausibility probes } \\
\text { - establish whether broader, more careful studies might be } \\
\text { 5. } \text { - } \text { - } \text { baluable } \\
\text { - tests of theory }\end{array}$ \\
\hline $\begin{array}{l}\text { Cunningham, } \\
1997\end{array}$ & $\begin{array}{l}\text { 1. The intensive case study (interpretative \& explanatory) } \\
\text { - The aim is to give the history, description or interpretation of } \\
\text { unique and common background or event. These event become } \\
\text { the essential to develop theory from an understanding of the } \\
\text { context in the event occur } \\
\text { 2. Comparative case study (case survey, case comparison \& creative } \\
\text { interpretation) } \\
\text { - It emphasizes the use of contrasting observation from various } \\
\text { setting and focus the clear concept of development. } \\
\text { 3. Action Research } \\
\text { - Define as a broad range of cases that highlight on research and } \\
\text { learning via intervening and alert the process of change. }\end{array}$ \\
\hline Edwards, 1998 & $\begin{array}{l}\text { 1. Descriptive (exploratory-descriptive, focused-descriptive) } \\
\text { 2. Theoretical- heuristic (grounded theory building, hermeneutic } \\
\text { work) } \\
\text { 3. Theory-testing (testing proposition within grounded theory, } \\
\text { metatheoritical construction) }\end{array}$ \\
\hline $\begin{array}{l}\text { Scholz and } \\
\text { Tietje, } 2002\end{array}$ & $\begin{array}{l}\text { 1. Holistic } \\
\text { - Qualitative design that lean on narrative, phenomenological } \\
\text { reports. Sometimes themes and hypotheses may be use but it's } \\
\text { remaining the underlying to the understanding of the case. } \\
\text { 2. Embedded } \\
\text { - Cases study that associate more than one unit of analysis and } \\
\text { not bounded to qualitative approach alone. }\end{array}$ \\
\hline Stake, 2005 & $\begin{array}{l}\text { 1. Intrinsic } \\
\text { - Initiate the better understanding of a particular case } \\
\text { 2. Instrumental } \\
\text { - A particular case that tested primarily to provide understanding } \\
\text { into an issue and to develop generalization. }\end{array}$ \\
\hline
\end{tabular}




\begin{tabular}{|c|c|c|}
\hline Gerring, 2007 & 6. & $\begin{array}{l}\text { Typical } \\
\text { - Representative, given the itemized relationship } \\
\text { Diverse } \\
\text { - More or less to be representative but in minimal sense of } \\
\text { representing the complete variation of the population } \\
\text { Extreme } \\
\text { - } \quad \text { Attainable only in comparison with a bigger number sample of } \\
\text { cases } \\
\text { Deviant } \\
\text { - After the case study is carried out, it may be corroborated by a } \\
\text { cross-case test } \\
\text { - That may include a brief hypothesis (a new variable) based on } \\
\text { the case study research. } \\
\text { Influential } \\
\text { - Normally not a representative } \\
\text { - Case (s) with the influential configurations of the independent } \\
\text { variables. } \\
\text { Most Similar } \\
\text { - Generally representative the most similar cases of the } \\
\text { - } \quad \text { Case (s) is similar on the stated variables other than } X_{1} \text { and/or } \\
\quad Y \text {. } \\
\text { Most Different } \\
\text { - Generally representative the most different cases of the } \\
\text { population might contribute the stable basis for generalization. } \\
\text { Case (s) is different on the stated variables other than } X_{1} \text { and/or } \\
\quad Y \text {. }\end{array}$ \\
\hline Levy, 2008 & 3. & $\begin{array}{l}\text { Idiographic ( Inductive/ Theory Guided) } \\
\text { - Focus to describe, clarify or explain a precise 'cases' by using } \\
\text { inductive or theory- guided approach. } \\
\text { Hypothesis-Generating } \\
\text { - Focus to discover beyond the data and to review one or more } \\
\text { cases for the purpose of generating more general theoretical } \\
\text { preposition. } \\
\text { Hypothesis- Testing } \\
\text { - Well-design case study can help in testing certain types of } \\
\text { hypotheses } \\
\text { Plausibility Probes (Pilot/ Illustrative Studies) } \\
\text { - Comparable to a pilot study in experimental/survey approaches } \\
\text { - To put the point on a hypothesis/theory and clarify the amount } \\
\text { of key variables. }\end{array}$ \\
\hline Yin, 2009 & 1. & Explanatory/Causal \\
\hline
\end{tabular}


Vol. 10, No. 2, 2021, E-ISSN: $2226-6348$ @ 2021 HRMARS

\begin{tabular}{|c|c|c|}
\hline & $\begin{array}{l}2 . \\
3 .\end{array}$ & $\begin{array}{l}\text { - Investigate the data firmly both at a surface and rooted in order } \\
\text { to define the phenomena in the data. } \\
\text { Descriptive } \\
\text { - To illustrate the natural phenomena which arise within the data } \\
\text { in the question } \\
\text { Exploratory } \\
\text { - Explore any phenomenon that appears in the data which can be } \\
\text { a vital point of interest to the researcher. }\end{array}$ \\
\hline Thomas, 2011 & $\begin{array}{l}1 . \\
2 . \\
3 . \\
3 .\end{array}$ & $\begin{array}{l}\text { Retrospective (Single- Case Study) } \\
\text { - Considers back on a phenomenon, individual and/or situation } \\
\text { and examine it in its historical principle. } \\
\text { Snapshot (Single-Case Study) } \\
\text { - The particular case is investigated in one specific time frame } \\
\text { such as a current event, a diary or a day in life of an individual. } \\
\text { Diachronic (Single-Case Study) } \\
\text { - Switch over time and quite similar with Longitudinal Studies } \\
\text { Nested (Multiple-Case Study) } \\
\text { - Concern with the comparison of elements in one case and the } \\
\text { mishap is within the principal unit of analysis. }\end{array}$ \\
\hline
\end{tabular}

In order to answer the research question on how learning strategy and style have impact to our Malaysian rural pupils, the descriptive case study by Yin (2009) might illustrate clear picture in answering the research question. According to Yin, descriptive case study approach is suitable to investigate a contemporary event- learning strategy and style. This particular type of case study is to describe the phenomenon occurred among Malaysian rural pupils in adapting learning strategy and style in their learning routine. This study captured the meaning that the Malaysian rural pupils subscribed to the learning strategy and style in context. This study presents a concrete and contextual data that allow the reader and researcher's interpretation.

\section{Strength and Misunderstanding of Case Study}

Once in a while everything is not as simple as they look, yet they are not as complicated as the look. Same goes to the approach in case study methodology. Researchers come out with their own point of view base on their background and experience.

The consistent of case study approach for both qualitative and quantitative research give a great impact to the research world. Cronin (2014) states the understanding and the adjustment of complexities in case study allows it to associates with the interpersonal process that develop in a wider social context. Many researchers acknowledge Cronin's view point and spot the strength of case study as one of research method. Flyvbjerg (2006) mentions that, the strength of case study is that the research in 'close' in real life situation. It might also view the case directly in relation to the phenomena as they develop in practice. The usage of case study has additional strength as well specifically in relatedness to daily life and case studies' affluence of individual aspect. Lindvall (2007) and Yin (2009) share the same opinion because case study will provide great benefit in allow the researcher to preserve a holistic views of real-life situation, such as life- 
cycles, the behaviour in small group, school performance and etc. The most noticeable advantage is the case study might cater an accurate analysis among the individual case.

Case study is crucial for researchers from two points of view. First, a case study is important to build different aspects of reality, including the attention that human behaviour cannot be accepted solely as an act that is directed by a rule or a theory. Secondly, case study can devote to the qualified development of a researcher, as case study able to provide concrete, context-dependent experience that increases their research expertise (Flyvbjerg, 2006).

Case study also offers essential evidence to complete the research. These are valuable aspects that help to explain 'how' and 'why' question by the researcher. They are also highly use when the researcher has limit to control over the events (Yin, 2009). Case study also prefer used by researcher when they deal with contemporary events that possible for them to manipulate the significant variable (Merriam, 2009). According to Murphy (2014), the approach in case study is non- prejudicial because focus group is just as questionnaires and participant of observation.

Noted that case studies are universally practice but underrepresented. Based on these findings, Gerring (2004) has classified a paradox in which he precisely states that a case study exists in a rare, curious methodological and he think is because to a lack of understanding of this approach. Flyvbjerg (2011) has therefore sought to clear up this paradox and to get a wider acknowledgement of research using case study. He has diagnosed five misunderstandings about case study that ruin the credibility and application of this research approach.

2011);

These misunderstandings refer basically to the theory, reliability, and validity (Flyvbjerg

a) General/theoretical (context-independent) knowledge is more beneficial than practical (context-dependent) knowledge. In order to clarify the misunderstanding, Flyvbjerg notes the concrete case knowledge is more beneficial for social science than the boastful search to predict the theory.

b) It is impractical to conclude on the basis of an individual case therefore, the case study cannot contribute to scientific development. Stake (2005) argues that a process of 'naturalistic generalization' appear from the indirect knowledge. That might answer the question "how things are?', 'why they are?', 'how they feel?' and 'how these things are likely to be later?'. Generalization is therefore potential by admit the similarities of the object/issues.

c) The case study is fruitful to generate hypotheses, while other methods are more suitable for hypotheses testing and theory building. But George and Bennett (2005) are convincing that case study method is suited for theory development because it gives a new formation of hypotheses and questions to study by variant cases.

d) Case study approach consists of bias in relation to its verification. So, that is the tendency to confirm researcher's bias impression. Thomas (2011) notes that case study can be precise when the researchers describe the whole research process in well-structured especially in analysis part.

\section{Conclusion}

To conclude, this article share some point of view about case study terminology, definitions, type of case study and its strength and misunderstanding. Case study should be understandable to accomplish its aims. The researcher should identify the purpose of the study. Case study 
approach gives researcher a chance to examine the data at a specific level and one of practical solution when a large sample of population is difficult to obtain.

By implement it in the study on how Malaysian rural pupils adapting in learning strategy and style. The researcher has a clear perspective in describing the data from the participant itself. Case study has its own setting in the social science strategies. It works better when its joint with other approach based on research framework. Case study is an established research methodology that is used broadly in several of field particularly in social science. In simple way case study designates as a line with a unknown message or a narrative that describes an actual or real- life situation in which a person or a group has to come out with a decision or to solve the problems.

\section{References}

Alarcon, A., Alcas, N., Alarcon, H., Natividad J., \& Rodriguez, A. (2019). Use of Learning Strategies in the University. A Case Study. Propósitos y Representaciones, $7(1), 10-32$. Retrieved from: http://dx.doi.org/10.20511/pyr2019.v7n1.265

Cope, D. (2015). Case study research methodology in nursing research. Oncology Nursing, 42(6), 681-882.

Cunningham, J. B. (1997). Case study principle for different types of cases. Quality and Quantity Journal. 31, 401-423.

Cronin, C. (2014). Using case study research as a rigorous form of inquiry. Nurse Researcher, 21(5), 19-27.

Easton, G. (2010). "Critical Realism in Case Study Research," Industrial Marketing Management (39), 118-128.

Eckstein, H. (1975). Case studies and theory in political science. In F. I. Greenstein \& N. W. Polsby (Eds.), Handbook of political science. Political science: Scope and theory, 7, 94-137, Reading, MA: Addison-Wesley

Elman, C., Gerring, J., \& Mahoney, J. (2016). Case study research: Putting the quant into the qual. Sociological Methods \& Research, 45(3), 375-391.

Flyvbjerg, B. (2006). Five misunderstandings about case-study research. Qualitative Inquiry, 12(2), 219-245.

Flyvbjerg, B. (2011). Case study. In: N. K. Denzin and Y. S. Lincoln (eds.). The Sage Handbook of Qualitative Research, 4th ed. Thousand Oaks, CA: Sage, pp. 301-316.

George, A. L., and Bennett, A. (2005). Case Studies and Theory Development in the Social Science. Cambridge: MIT Press.

Gerring, J. (2004). What is a case study and what is it good for? American Political Science Review, 98(2), 341-354.

Green, J., and Thorogood, N. (2009) Qualitative methods for health research. Sage, London.

Gustafsson, J. (2017). Single case studies vs. multiple case studies: A comparative study (Literature review). Retrieved from: http://www.divaportal.org/smash/get/diva2:1064378/FULLTEXT01.pdf

Hammersley, M. (2012). Troubling theory in case study research. Higher Education Research \& Developement, 31(3), 393-405 
Lazar, J., Feng, J. H., \& Hochheiser, H. (2010). Research methods in human-computer interaction. Hoboken, NY: John Wiley

Marsella, N. R. (2018). Critical and Creative Thinking in General Education: A Descriptive Case Study. Dissertations, Theses, and Masters Projects. Paper 1550153949. Retrieved from: http://dx.doi.org/10.25774/w4-kcrj-rt68

Merriam, S. B. (2009). Qualitative research: A guide to design and implementation. San Francisco, California: Jossey-Bass.

Miles, M. B. (1979). Qualitative data as an attractive nuisance: The problem of analysis. Administrative Science Quarterly, 24(4), 590-601.

Mills, A. J., Durepos, G., \& Wiebe, E. (2010). Encyclopedia of Case Study Research. Los Angeles: Sage Publications

Murphy, M. (2014). What are the benefits and drawbacks of case study research? Retrieved from http://socialtheoryapplied.com/2014/05/24/benefits-drawbacks-casestudy research/ [2019-12-02]

Scholz, R., \& Tietje, O. (2002). Embedded Case Study Methods: Integrating Quantitative And Qualitative Knowledge.

Siggelkow, N. (2007). Persuasion with case studies. The Academy of Management Journal, 50(1), 20-24.

Simons, H. (2009). Case study research in practice. London: SAGE. Stake,

Stake, R. (1995). The art of case study research (pp. 49-68). Thousand Oaks, CA: Sage.

Sturman, A. (1997). Case study methods. In: J. P. Keeves (ed.). Educational research, methodology and measurement: an international handbook (2nd ed.). Oxford: Pergamon, pp. 61-66.

Thomas, G. (2011). A Typology for the case study in social science following a review of definition, discourse and structure. Qualitative Inquiry, 17(6), 511-521.

Verschuren, P. J. M. (2003). Case study as a research strategy: some ambiguities and opportunities. International Journal of Social Research Methodology, 6(2), 121139.

Verschuren, P. (2003). Case study as a research strategy: Some ambiguities and opportunities. International Journal of Social Research Methodology, 6(2), 121-139.

Yin, R. K. (2002). Case study research: Design and methods. Thousand Oaks, CA: SAGE Publications.

Yin, R. K. (2009). Case study research: design and methods (4th ed.). Thousand Oaks, CA: Sage.

Yin, R. K. (2013). Validity and generalization in future case study evaluations. Evaluation, 12(1), 219-245

Zaidah, Z. (2007). Case study as a research methodology. Jurnal Kemanusiaan, 5(1), Retrieved from: http://psyking.net/htmlobj3837/case_study_as_a_research_method.pdf 